\title{
NOTES ON THE LONTARA' AS HISTORICAL SOURCES*
}

\author{
Andi Zainal Abidin \\ Translated by the Editors
}

In the broadest sense, the word Zontara' applies to anything written in the Bugis-Makasar script. This script is called urupu sulapa' eppa' (sometimes appa'), or square letters, in the Bugis, Makasar, Mandar, Duri, Enrékang, and Toradja languages. ${ }^{1}$ One can divide lontara' into categories according to their subject matter.

The lontara' attoriozong are chronicles about the "people of the olden days," and they contain historical facts. The lontara' bilang, or kotika, describe the days of the week, giving the characteristics of each and indicating which ones are considered auspicious. Lontara' ade', or ada', contain notes on adat 1 aw and custom; these are called latowa in Bugis-speaking areas and rapang in Makasar language areas. The lontara' $u l u$ ada (Bugis) and lontara' ulukanaja (Makasar) are collections of the texts of treaties with nearby kingdoms or with overseas countries. In Bugis areas, one also finds government contracts, called rapang, which were drawn up between elected kings and the representatives of the people. The lontara' allopi-loping are collections of adat law pertaining to shipping, such as those in the compilation made by La Pate110' Amanna Gappa. ${ }^{2}$ The lontara' pangoriseng relate the genealogies of the various radja. In Gowa, there exist also royal diaries which probably date from the period after contact with the Portuguese, roughly the sixteenth century; ${ }^{3}$ they use Portuguese dating until 1605, when they switch to

* This article is a revised and shortened version of a paper presented to the Second Seminar on National History, held in Jogjakarta, in August 1970 .

1. The 1ontara' of the radja of the Mandar, Duri, Enrékang, and Sangalla'-Toradja regions were generally written in the Bugis language, as the royalty of these areas had genealogical ties to the Bugis aristocracy.

2. Ph. 0. L. Tobing, et. al., Hukum Pelajaran dan Perdagangan Amanna Gappa (Makasar: Jajasan Kebudajaan Sulawesi Selatan dan Tenggara) and L. J.J. Caron, Het handels-en zeerecht in de adatrechtsregelen van den Rechtskring Zuid-Celebes (Bussum: C. A.J. van Dishoeck, 1937) identify the author of this work only as Amanna Gappa, that is, the "father of Gappa." I obtained his original name, La Pate110', from Hadji Andi Ninnong, the former Ranreng Tuwa of Wadjo'.

3. One of the 1ontara' mentions that the Portuguese took two sons of Datu Suppa' to Europe where they each obtained a degree from the University of Paris. Consequently, many nobles from Gowa and Suppa' were fluent in Portuguese, French, and Latin. 
Islamic dates. In Bugis areas, diaries similar to these are often contained in the back pages of lontara' attoriolong. ${ }^{4}$ The term lontara' is often applied as well to agricultural manuals, called lontara' pallaoruma, and to books of medical lore, called lontara' pabbura.

Although many different kinds of lontara' exist, the largest single group consists of brief notes on important historical events or subjects. These can serve as useful preliminary sketches for writing the history of South Sulawesi. Sometimes the notes are scattered in other works and sometimes gathered together in small collections. Occasionally, Islamic and/or Christian dates are appended to the notes. If written in the Bugis or Makasar epic prose style, the notes are called to $0^{\prime}$. They were usually chanted before an audience in the meeting ha11, in the presence of the radja and his court. Sometimes such recitations were accompanied by a type of violin called a késo-késo.

The tolo' recount the heroism of famous warriors-for example, the Tolo'na Boné which describes the resistance of Boné against the Dutch in 1905. The story of an important event or historical figure mentioned in the tolo' was frequently embellished with legends and improbable tales. Such fantastic embellishments served to stretch out the story and to enliven the general atmosphere. The narrator invariably warned the audience that not everything which he would relate would be true. At the beginning, or in the middle if the people had begun to nod or seemed bored, the storyteller would say: "They say I am telling lies, but the listener is the greater liar because he knows that what he hears is untrue but he consents nonetheless." The agreement of the audience, including the radja, was an integral part of the narration. Consequently, these stories are called pau-pau rikadong, which means roughiy "a tale which must be agreed to whenever the narrator pauses for a breath."

Some Bugis, particularly among aristocratic circles in Luwu' but also elsewhere, consider the $I L a$ Galigo literature as a lontara' chronicle. The I La Galigo contains the myths of the legendary Sulawesi radja La Patiganna, known as Adji' Sangkuru Wira, and his descendants. The main figures in this body of literature are La Ma'dukeileng, known as Sawérigading, and his son I La Galigo. Certainly, this work must rank among the longest pieces of literature in the world--European scholars alone assembled about 6,000 folio pages of it. ${ }^{5} \mathrm{H}$. J. Friedericy has said of this work: "Ethnologically, it is, without any doubt, the

4. A cousin of mine actually saw such a diary, that of La Ma'dukelleng, Arung Singkang, Sultan Pasir, a man who ruled the waters between Malaka and the Makasar Straits from about 1720 to 1736 . The diary was in the possession of the former Sultan of Bulongan in East Kalimantan.

5. R. A. Kern, Catalogus van de Boeginese tot de I 1a Galigo-cyclus behorende handschriften (Makasar: Jajasan Matthes, 1954). This does not include the large number of folio pages still dispersed within the Bugis community. Dr. B. F. Matthes, Boeginesche Chrestomathie (Makasar and Amsterdam: Bijbelgenootschap, 18641872), Vo1. II, pp. 416-537, notes 250-253. 
most valuable piece contained in the two chrestomathies of Matthes." 6

At the time the I La Galigo was written, only a few Bugis literary works already existed. They described conditions in the kingdoms of Luwu' and Tjina (Pammana), some time prior to the fourteenth century when the Bugis people stili lived along the coast--probably during the era of Srivijaya's greatness. Like the Babad and Hikajat of other archipelago ethnic groups, which, as Hoesein Djajadiningrat has said, have at the very least a "symbolic value," the Bugis works contain useful historical evidence. I would not go so far as to assert that the I La Galigo should serve as the main source for research on pre-fourteenth-century Bugis history, but, given the scope and nature of Bugis literary works, its importance as an historiographic record should not be totally dismissed. In the seventeenth, to eighteenth centuries, to take yet another example, Amanna Gappa," who came from Pammana, compiled the adat law regulations governing shipping and trade. His work served as the basis for a 1937 doctoral thesis by L. J. J. Caron. ${ }^{8}$

The I La Galigo itself forms a source for the later. belief that the first kings of South Sulawesi were descendants from the sky called Tomanurung (lit., he who came from the sky). This belief is restated in the beginning of every lontara' chronicie. 9 Most ruling families have taken their names from the I La Galigo, hoping perhaps that the namesakes would follow in the epic and heroic footsteps of the legendary ancestors.

The "literary" I La Galigo contrasts with other lontara', such as the Palzontara' 1ontara', in the general approach taken by the authors. The author of the 'PaIZontara' was clearly less influenced by myths and fables than the author of I La Galigo; rather he tried to present historical evidence in a rational manner.

\section{The Origin of the Term Lontara'}

Dutch scholars, principally Noorduyn, Cense, and Matthes, believe that the word 'Iontara' was adopted from "outside," that is, from Bali or Java. Matthes argues that lontara' corresponds to the Javanese/Malay word lontar, which was a transposition of rontal. Rontal, he said, was a combination of the Javanese words ron (1eaf) and tai. Tal applies to a particular kind of tree--the Borassus flabeliformis L. --whose leaves could be written upon with a stylus.

6. H. J. Friedericy, "Die standen bij de Boegineezen en Makassaren," Bijdragen tot de Taal-, Land-en Volkenkunde, 90 (1933), p. 582 .

7. Hoesein Djajadiningrat, "Local Traditions and the Study of Indonesian History," in Soedjatmoko (ed.), An Introduction to Indonesian Historiography (Ithaca: Cornell University Press, 1965), p. 84.

8. Caron, Het handels - en zeerecht

9. The only exception is the Lontara' Lengkap Wadjo', composed by La Sangadji Puanna La Sengngeng (1764-1767). A copy of this lontara' is available at the Institute for South and Southeast Sulawesi Culture, in Makasar (ms \#273). 
The tree is called ta' in Bugis, tala' in Makasar and tala in Sanskrit. According to Matthes, lontara' meant first the leaf of a lontar tree and eventually just any written work. ${ }^{10}$

According to Andi Makkaraka, an expert on and collector of lontara' in Wadjo', the earliest lontara' were composed in Luwu' before writing was known in other regions. The Luwu' writing was called sure' (the same word as surat, or document). At first, the people of Luwu' used leaves from the aka' tree (Corypha Gebanga B1.). Andi Makkaraka once came across a version of the I La Galigo which was written on aka' leaves and which used an eighteen-letter alphabet.1 ${ }^{11}$

Subsequently, lontara' appeared in other Bugis areas, notably Gowa and Ta110'. These date from the reign of the ninth radja of Gowa, titled Daéng Matanré, Karaéng Mangutungi, who was known as Tumapa'risi' kallonna (the man with the lame neck) and who reigned from about 1510 to 1546. The shahbandar (harbor master) Daéng Pamatté, who was appointed the Tumailalang (Minister of Internal Affairs), began writing a lontara' pattorioloang-chronicles of men in olden times. He used raung tala' leaves and wrote in a Makasar alphabet which was a modified version of the square letters used in Luwu'. After the people of Gowa came in contact with the Portuguese, in 1538, they first became acquainted with paper. Beginning in the sixteenth century, after the arrival of the Portuguese, the rulers of Gowa and Ta110' began keeping diaries.

In 1605 , during the era when Is lam had begun to penetrate Gowa, an Islamic propagandist from Minangkabau, Abdul Ma'mur Chatib Tunggal, with the title Dato' ri Bandang, enriched the square alphabet with the letter ha--thereby making it possible to transliterate Arabic terms. Subsequently, Arung (king) Pantjana, called Tjolli' Pudjié, whose death title was Matinroé ri Putjé (he who entered the fray in Putjé-Lamuru), added four more basic letters--corresponding to the sounds mpa', ngka', ntja' and nra'-. which brought the basic Bugis-Makasar alphabet up to 23 letters.

The long history of writing in Sulawesi casts doubt on the opinion of the Dutch experts that the term lontara' originated from outside the region. The people of Gowa had long used the term raung tala' and the Bugis the term daung ta'. The people of Gowa also claim that the place where the lontar leaves grow was once ruled by the kingdom of Gowa. ${ }^{2}$ This claim may be a bit exaggerated, but it does indicate a presumed long acquaintance with the lontar leaf. The similarity of the Sulawesi term with

10. B. F. Matthes, Boegineesch-Hollandsch Woordenboek (The Hague: M. Nijhoff, $187 \overline{4}$.

11. A. Abubakar Punagi, "Tjeritera Orang Dahulu Kala jang MulaPertama Ditulis pada Dedaunan Digulung dan Kelak Kemudian Dikenal sebagai Asa1-Mula 'Tulisan Bugis', Dikumpulkan oleh A. Makkaraka Petta Bétténg di Wadjo'," Bingkisan Jajasan Kebudajaan Sulawesi Selatan dan Tenggara, No. 6 and No. 7 (1967).

12. This claim was reported by the last king of Gowa, Andi Idjo Karaéng Lalolang. 
that used in Java and Bali is quite understandable since the languages of all three areas belong to the same general linguistic family.

\section{The Lontara' on Historical Subjects}

In its strictest sense, the term lontara' is applied only to those writings in the Bugis-Makasar language and script which recount the history of kings and kingdoms. Formerly, such chronicles were called attoriolong (Bugis) and pattorioloang (Makasar). Lontara' concerning the "people of ancient times," or "prehistoric" era, and written on lontar leaves are a great rarity. They exist only among the Tolotang ${ }^{13}$ people in the Sidénréng area. These people believe that the spirit of the ancestors serves as the medium for prayers to the gods. ${ }^{14}$ No expert on antiquities has ever examined these lontara' and thus the date of their writing has never been precisely determined.

The lontara' which Noorduyn studied date from the eighteenth century, though some were originally composed in the seventeenth. ${ }^{15}$ These, however, were already written on paper not on lontar leaves. They rarely numbered more than 50 pages. One exception is an authentic Iontara' from Wadjo' which comes to more than 600 pages. According to Andi Makkaraka, it was composed by the Arung Béttémpola, ${ }^{16}$ La Sangadji Puanna La Sengngeng, on orders from the thirty-fourth Arung Matowa of Wadjo', 17 known as La Mappapadjung Puanna Salowong, who reigned from 1764 to 1767 . It compares all the

13. The Tolotang people are generally referred to in Wadjo' as the Pattotoni because, according to the story, they originated from the village of Taoni in Wadjo'. They left Wadjo' in 1609 when Islam began to spread there. They claim to be Muslims but rarely observe Islamic practices.

14. They believe in Déwata Séuwwaé, that is, the One Supreme Lord who because his habitation is unknown, cannot be communicated with directly.

15. J. Noorduyn, "Origins of South Celebes Historical Writing," in Soedjatmoko (ed.), An Introduction to Indonesian Historiography, p. 143 , note 18 .

16. The Arung Béttémpola headed an administrative district called a limpo. He was a senior member of the council of the radja (the Petta Ennengngé, Our six Lords) and of the council of adat chiefs (the Arung Patappulo, the Forty Radja), spokesman for the kingdom, the official charged with appointing and dismissing the Arung Matowa Wadjo' (the senior radja), and the highest ranking official protecting the civil rights of the people against abuse by authority.

17. The Arung Matowa, or senior radja, served as the chairman of the Council of Six Radja and the Council of Forty Radja. He was selected by the Council of Forty Radja who could also dismiss him. Candidates were expected to be descendants of the founder of the kingdom, intelligent, gentleman1y (kesatria), wealthy, and honest. 
1ontara' then available in Wadjo' together with hundreds of others from Gowa, Boné, Soppéng, Luwu', Sidênréng, Suppa', and other areas. The resulting work is known as the Lontara' Sukku'na Tanah Wadjo', the Complete Chronicles of the Land of Wadjo'. I8

A. A. Cense never read this chronicle, but he did refer to its existence, noting that: "Chronicles continued to be produced up to relatively recent times; those of Wadjo', for example, date to the middle of the nineteenth century."lg Noorduyn likewise had no chance to read this particular lontara', but he also knew about it: "In the possession of the Matthes Foundation in Makasar, there is an uncatalogued transcript consisting of some 600 folio pages written in Bugis script which deals with the history of Wadjo'. It was assembled shortly before the war by Arung Béttémpola La Makkaraka. It seems unlikely that this copious work represents a wholly new historiography." 20

I myself have never read a lontara' so voluminous as this one belonging to Andi Makkaraka. He himself continued the work begun in the Lontara' Sukku'na Tanah Wadjo' using historical material on the Bugis-Makasar region which he had collected as well as compendiums of Bugis adat 1 aw and 1 ists of royal genealogies from South Sulawesi. The Complete Chronicles of Wadjo' form an invaluable aid for the study of ungakapan, instructions on proper formulae for treaties and government contracts, for it contains the official interpretations of various symbolic references which are no longer widely understood. The chronicle differs from other lontara' in that the opening does not mention the Tomanurung rulers. Moreover, it does not recount the set formulae pertaining to the personality cult in praise of the Tomanurung, as in the lontara' pattorioloang of Gowa, Boné, Soppéng, Luwu', and others.

Most lontara' are organized according to the sequence of important events occurring during the reigns of the particular kings, and they vary in size from ten to fifty pages. Some close$1 y$ follow a dynastic format and give brief notes on the kings according to the chronology of their reigns. In many cases, the early kings are referred to only by their titles, although the full names may frequently be found by checking the royal family genealogies. These titles vary widely. Sometimes they accord with some physical characteristic, for example, the Radja Boné Botée (the fat radja of Boné), or Radja Gowa Tumapa'risi' kallonna (the radja of

18. As far as I know, there exist no other lontara' as complete as this one. Moreover, it has additional value because it contains very few mythical elements. Succeeding generations after La Mappapgdjung continued adding to the chronicles, which consequently transcribe important events in South Sulawesi up to the end of the nineteenth century. The original copy of the lontara' is in the possession of the family of Andi Makkaraka in Séngkang.

19. A. A. Cense, "Enige aantekeningen over Makassaars-Boeginese geschiedschrijving," Bijdrage tot de Taa1-, Land- en Volkenkunde, 107 (1951), pp. 42-60.

20. J. Noorduyn, Een achttiende-eeuwse kroniek van Wadjo', (The Hague: H. L. Smits, 1955), p. 4 . 
Gowa with the lame neck). Sometimes the titles are connected with localities, such as the Karaéng Bontomangapé (Prince of Bontomangapé) or the Aru' Palakka (Prince of Palakka). A ruler may be known by the manner or place of his death, as the Tumenanga ri Balla'pangkana Tunibatta (the one who was hacked) or Djamménga ri lawo-lawona (he who died in the ammunition dump). In another instance, the title refers to the way the ruler left the throne, i.e., Tunipassulu' (he who was dismissed). The use of titles rather than names was a consequence of the ancient belief that the original names of kings could not be mentioned. The rulers were considered to be puang mallinota, our visible lord; they were regarded as the representatives of God who were destined to rule. The existence of this belief shows up very clearly in the I La Galigo.

The lontara' attoriolong are remarkable because they tend to relate events in a matter of fact way and without excessively flattering the ruler. The lontara' Gowa, for example, relates that the mother of the ninth radja of Gowa, Daéng Matanré Karaéng Mangutungi, Tumapa'risi' kallonna (1512-1548) was the budak (servant) of a lime seller in Tal10'.21 Had he so desired, the king or his successor could doubtless have executed the author of the lontara' for using the work budak--or the phrase "the man with the lame neck." The lontara states with regard to the tenth ruler of Gowa, I Mariogau' Daéng Bonto, titled Karaéng Lakiung Tunipalagga Ulaweng (1546-1565), that he was not known for sincerity, honesty, or wisdom, only bravery. As in the former case, the descendants of I Mariogau' could easily have eliminated the lontara' which contained this slur on their predecessor. Concerning the king of Boné, La Itja', titled Matinroé riadénénna (he who entered the fray on his staircase), who reigned from 1584 to 1602 , it is said that his people murdered him because he was so cruel. 22 That rulers showed little inclination to tamper with the lontara' enhances the historical credibility of the documents.

In addition to their rather frank comments about royal shortcomings, lontara' writers were also quick to assert their own ignorance of the facts when they did not wish to take responsibility for what they reported. For example, the abovementioned lontara' Gowa states with regard to the early kings of Gowa: "Concerning Tunatangka'lopi (the sixth ruler) and Tumasalangga Barajang (the second ruler), neither their wives nor children are known. It is said only that they inherited the government. Nor is anything known about their wars, nor how long they ruled, because at that time the lontara' did not yet exist." 23

21. G. J. Wolhoff and Abdurachim, Sedjarah Goa (Makasar: Jajasan Kebudajaan Sulawesi Selatan dan Tenggara, n.d.). According to La Sidé, the last ruler of Gowa (Andi Idjo Karaéng Lalolang) once stated that the mother of Tumapa'risi' kallonna was not truly a slave but in fact the daughter of a Bugis (or Mandar) aristocrat who had been abducted by her nurse. The latter took shelter in the ship of a lime trader from Ta11o'. The girl reportedly wore gold ornaments of a type usually worn by BugisMakasar girls. The ruler of Gowa reared her and later married her to his son.

22. Noorduyn, "Origins of South Celebes Historical Writing," p. 140.

23. G. J. Wolhoff, Sedjarah Goa. 
The Iontara' contain few mythical elements though at the beginning one does find the Tomanurung legend. Although the authors perhaps felt compelled to include these stories the narration makes clear that they disavowed any responsibility for the veracity of the "tale of the first kings." The description runs roughly as follows: "People in olden times called him (the first king) Tomanurung because no one knew where he came from or how he died;" or, alternatively, "because no one knew his father and mother." A Iontara' from Wadjo' 24 refers to the first king not as the Tomanurung but as the Toripatompo' (the man who was caused to appear). The legendary first ruler of Boné, titled Matasilompoé, the first ruler of Soppéng, La Temmamalla titled Manurung di Sékkanjili', and the husband of the first ruler of Gowa, Karaeng Bajo', are identified simply as the first rulers who were sent by their father Datu Luwu' to reign respectively in Boné, Soppéng, and Gowat. Their reigns reportedly began seven pariamang (similar to a Javanese windu, that is, eight years) after the kings mentioned in the I La Galigo. According to the I La Galigo, the ruler Sawérigading and his descendants had all drowned while returning from a family celebration in Luwu'. With no radja nor adat to regulate society, anarchy persisted for seven generations and "men swallowed each other up like fish." This chaos ended when the gods sent the first radja, himself said to be a descendant of Sawérigading.

Scholars generally have been impressed with the reliability of the lontara's reporting. Noorduyn noted that: "The Bugis and Makasar chronicles.. reveal tendencies quite the opposite to the ones of Java. Their writers have clearly tried to dis associate themselves from the mythological and legendary elements that they had to include because they found them in their sources." 25 Cense noted that the high degree of accuracy displayed in the lontara' accords with the level of achievement of the South Sulawesi people in other fields-making of geographically precise maps; codification of laws; management of capital including extensive inventory keeping; and registration of careful data about weapons, houses, and ships. Cense asserted that, as a consequence: "The historian who wants to write about South Sulawesi will find a treasure of indispensible data in the material recorded and collected in the area itself. If the sources are systematically exploited, moreover, they can add to the knowledge of the history of neighboring regions in eastern Indonesia." 26

One may ask why the Bugis, Makasar, Mandar, and Toradja aristocrats produced a historiographical literature unique in Indonesia. The answer, in great measure, stems from the character, beliefs, and experiences of the people themselves. In 1907, the Assistant Resident of Boné, de Greeve, describing the character of the South Sulawesi peoples, said: "They are not shy about

24. Chronicle of Andi Bataritodja, Datu of Gilireng.

25. Noorduyn, "Origins of South Celebes Historical Writing," p. 138. Cense has also noted this "businesslikeness," as he cails it, of the lontara' style. Cense, "Enige aantekeningen."

26. Cense, "Enige aantekeningen." 
expressing their complaints concerning any improper behavior by the authorities. They love justice and have no hesitation in leaving their country if they feel oppressed." 27 It is also significant that the Hindu religion exercised little influence over South Sulawesi; therefore, the Hindu literary style, with its emphasis on myths, legends, and symbols, did not become established there.

The people of South Sulawesi, as individuals, have always paid great attention to their history. Many local families possess chronicles documenting important events in the history of their lineage, or diaries of events covering varying periods of time, or anthologies containing information and transcriptions from assorted other manuscripts. All these types of writing fall into the category of Iontara'. The Iontara' written by one generation were bequeathed to the succeeding generation which then recorded important events of its own time. Recorded events were not limited to purely local matters, and, as a result, to write the history for a given area requires comparison of numerous lontara' from all over.

Non-Chronicle Lontara'

As noted earlier, not all lontara' were intended as chronicles of events, but even the "non-history" lontara' furnish information for the scholar of South Sulawesi history. One finds, for example, collections of brief notes often dated according to the Muslim and/or Christian calendar. The date may refer, however, to the original notation or to the subsequent copying of it. The notes were generally written in long notebooks in rather dry, non-1iterary prose. Few of the original collections remain extant.

Some people, principally in Gowa, kept personal diaries. The only non-Gowa diary known is that of La Ma'duke1leng Arung Singkang, Sultan Pasir (1726), which he kept while overseas in Malaka and Kalimantan. Unfortunately, this diary is no longer accessible; the person who had custody of it, the former Sultan of Bulongan, was killed by the communists. Such diaries, often covering several decades, are common primarily among peoples influenced by Makasar and Bugis culture. In the seventeenth and eighteenth centuries, for instance, the idea of keeping a diary was brought to Bima along with other South Sulawesi court customs. ${ }^{8}$ The diaries used Christian, or a combination of Christian and Islamic, dates with the names of important months in Bugis-Makasar language.

Another form of lontara' are the notes on treaties between kingdoms, called ulu ada (Bugis) or uluhanaja (Makasar). A large portion of the Corpus Diplomaticum Gowa is today preserved at the Institute for South and Southeast Sulawesi Culture. The Complete Chronicles of Wadjo' discusses most of the treaties negotiated between the kingdoms of the fifteenth to eighteenth centuries. An example of

27. Bestuursmemorie of Assistent Resident of Boné de Greeve, 1907.

28. Cense, "Enige aantekeningen." 
such a treaty is that of Tellumpocho, which cemented an alliance between the kingdoms of Boné, Soppéng, and Wadjo'. Drawn up in 1582, in the village of Bunné, Timurung, Boné, it created a mutual defense pact against the kingdom of Gowa, then beginning to expand as the successor to the kingdom of Luwu'. More important, however, the Tellumpocho treaty represented the first attempt to standardize the adat law used in the three kingdoms and thereby to provide uniform treatment for the citizens of al1. ${ }^{29}$ The three kingdoms also later convened a joint law court to hear a particularly difficult case. ${ }^{30}$

South Sulawesi kingdoms, in former times, exchanged diplomatic representatives. The Bugis states in particular had an organized system of envoys who possessed diplomatic privileges and immunities. By the sixteenth century, the kingdoms had worked out relatively fixed boundary lines. ${ }^{31}$ The complete Chronicles of Wadjo', for example, outlines the boundaries for the kingdoms of Luwu', Boné, Wadjo', Gowa, and others--giving the rivers, hills, lakes, trees, villages, wanuwa (regions), and boundary stones (called batu manu, meaning literally stone cocks), which marked their borders.

Copies of correspondence among kingdoms, regions, and foreigners were retained. Called Tuladang, they were transcribed into albums, on the empty pages of diaries, or in the chronicles.

Royal genealogies form another important source for South Sulawesi history. In Bugis areas, these are called pangoriseng. They begin with the first known king and often continue up to the present time. Known genealogies include those of Hadji Andi Mappanjukki' (former radja of Boné), Andi Idjo (former radja of Gowa), Andi Oddang (former radja of Boné), Andi Idjo (former radja of (former Arung Matowa of Wadjo'), Andi Makkaraka (former Arung Béttémpola), Andi Djémma (former Datu of Luwu'), and Hadji Andi Baso (former Datu of Tanété). ${ }^{32}$

Genealogies often provide a useful means for doublechecking the contents of the chronicles. If a discrepancy exists, obviously the historian must examine all the evidence even more closely. One example of conflict concerns Wé Tadampali who is mentioned in many lontara'. She is said to be the daughter of the Datu of Luwu' who,

29. G. J. Resink, "The Significance of the History of Internationa1 Law in Indonesia," in Soedjatmoko (ed.), An Introduction to Indonesian Historical Writing, pp. 360-361.

30. A. Z. Abidin, "Peradilan Antara-Keradjaan jang Uniek pada Abad Ke-XVI di Daerah Bugis," Hukum Nasiona1, No. 3 (1969).

31. Resink, "The Significance of the History of International Law," p. 360 .

32. Abdurazak Daéng Patunru' compiled the most complete genealogies available for a11 the well-known rulers of South Sulawesi. He was himself an important historian of Sulawesi. Noorduyn's dissertation also contains an appendix of genealogies, among them, those of the Arung Matowa Wadjo', Ranreng Bêttémpola, Ranreng Talo'tenréng, and oRanreng Tuwa. He relied on lontara' preserved in Leiden. Noorduyn, "Een achttiende." 
reputedly, had a skin disease but was cured after being licked by an albino water buffalo. The princess supposedly married a son of the radja of Boné and founded the kingdom of Wadjo'. The genealogy retained by Andi Makkaraka, however, does not credit Wé Tadampali as the founder of Wadjo'. 'It lists her as the daughter of the tenth Datu of Luwu', named La Mallalaé. The mother of Wé Tadampali, called Radja Manai', was the daughter of Ma'dika Sangalla'. She was related to the eleventh Datu of Luwu', To Sangereng Déwaradja, with the title Datu Kélali, known as Dangkélali (the king with a cock's comb) by the Toradja because one of his cheeks was red like a cock's comb. Dewaradja, according to the Complete Chronicles of Wadjo' and two other lontara', concluded a treaty with the fourth Arung Matowa of Wadjo', known as La Tadampare' Puang ri Maggelatung (c. 14901520), who attacked Sidénréng. Déwaradja unsuccessfully waged war against the fifth radja of Bone, La Tenrisukki', and in the subsequent peace treaty the ceremonial umbrella of Luwu' was transferred to Boné. La Tenrisukki', therefore, received the title Mappadjungngé (the one with the ceremonial umbrella). Though many legends state that the heroine We Tadampali married his son, in the genealogies she is recorded as having married La Malu' To Angingradja, the Arung Saotanré, who was the son of La Tenritau', the Paddanreng (Pendamping) of the petty kingdom of Tjinnotabi' (east of Tosora in Wadjo'). He was not the king of Wadjo' because at that time no kingdom of Wadjo' existed; he was only the head of a region.

The importance of checking the genealogies can be seen in an example from Noorduyn's dissertation. Noorduyn says that La Tiringeng To Taba', the Arung Saotanré (known for his "contract" with the people of Wadjo' which stipulated their social rights) was a homo novus, that is, the descendant of a Tomanurung from Sangalla'-Toradja. However, the genealogies assign him a more mundane status. Rather than being a newcomer or the descendant of the people from heaven, according to the genealogies, he was the son of La Tenreadji', Arung Sailong (Bonê). His mother was Wé Tjamekku', a third degree descendant of La Tenribali, the fifth Arung of Tjinnotabi'.

The genealogies can also shed light on the actions of important historical figures, for family ties often determine political actions. For example, the thirty-third Arung Matowa of Wadjo', La Tenrilai' To Senggeng, came to the aid of the radja of Gowa, I Mallombasi Daéng Mattawang, Karaéng Bontomangapé, known as Sultan Hasanuddin (16531669), in the latter's fight against the Dutch and their ally the Arung of Palakka', La Tenritatta' To Unru' Daéng Sérang. La Tenrilai's action in fact contradicted the terms of the three power treaty of 1582 between Boné, Soppéng, and Wadjo'. La Tenrilai' rationalized that the treaty did not apply because of the foreign intervention. But the real reason, according to Andi Makkaraka, was that La Tenrilai' had married Sultan Hasanuddin's daughter. This relationship also helps explain why La Tenrilai' remained with Sultan Hasanuddin even though the latter warned him: "Gowa has been destroyed. Oh my children, return home and pursue the welfare of our country of Wadjo'. Later you will rejoin Gowa in good fortune." La Tenrilai' stayed and was eventually killed.

During the Dutch colonial period, the genealogies had an added importance because individuals of certain rank were exempt from the state and municipal labor services. To enter the colonial civil service academy, a candidate had to present a genealogy (approved by a local genealogical committee) indicating his social position. 
Notes on adat law provide important information for scholars of South Sulawesi. They were often collected into separate books; in Boné, Soppéng, and Wadjo', these compilations were called Latowa (the old one). They contain adat regulations and also aphorisms by famous adat thinkers--such as To Méggu Matjtjaé, fifteenth-century Luwu', La Méllong Kadjaolaliddong, sixteenth-century Boné; La Tadampare' Puang ri Maggalatung, La Tiringeng To Taba', and to Maddualeng, fifteenth-century Wadjo', and La Pagala Néné Mallomo, sixteenth-century--concerning proper behavior for rulers who wanted their subjects' respect.

In addition to the information these notes furnish on specific adat law provisions, they also document changes in social structure in South Sulawesi society. The people themselves recognized that society was not static. One ruler of Gowa, Abd. Al-Djalil To Ménanga" ri Lakiung (1677-1709), went so far as to say: "After my death, if it is found that anything done on my account was wrong, then it should be undone. It is a good deed for the sake of the dead to correct what they have done wrong." ${ }^{33}$ Thus the notes shed light on the changing position of the king. Before the seventeenth century, one can find kings with virtually absolute power everywhere but in Wadjo'. Over time, their power became circumscribed, and, in some kingdoms, such as Luwu', the king came to represent mainly a unifying symbol. A Luwu' adat law provision reads: "Decisions of the Datu ( $\operatorname{adja}$ ) may be nullified, but decisions of the council of adat chiefs may not. Decisions of the council of adat chiefs may be nullified but decisions of the Anang may not. Decisions of the Anang may be nullified, but decisions of the masses may not."34

The adat law notes describe the decision-making process for determining adat law as follows: "If one is against two, then the one gives way. If it is three against one, then the one is defeated--all the more when all are against." Obviously fifteenthcentury Wadjo' was already using a system of voting, as opposed to the consensus system, mupakat or sekato, common elsewhere in Indonesia. ${ }^{35}$ This evidence belies the assertion that the system of voting was introduced from Europe, for the men of Wadjo' were not yet acquainted with either Europeans or Muslims. Ph. Tobing has concluded from this that: "In those days, Wadjo" society was animated by a democratic spirit which acted as a motor or stimulus. In this regard, the Wadjo' region is unique

33. Cense, "Enige aantekeningen."

34. G. H. N. Riekerk, "Lahirnja kedatuan Tomanurung," lecture to the law faculty, University of Hasanuddin, August 13, 1969 and my comment entitled, "Perkembangan kekuasaan Datu Luwu' jang sepandjang jang sampai pada kita melalui keterangan 2 orang 2 Luwu ", Bingkisan Jajasan Kebudajaan Sulawesi Selatan dan Tenggara, Nos. $1 / 2$ and 3/4 (1969).

35. A. Z. Abidin, "Demokrasi Pantjasila," paper to the Pantja Sila Seminar in Makasar organized by Hasanuddin University in 1967 (stencil, Hasanuddin University, 1967). 
in South Sulawesi." 36

Problems of Using the Lontara' as Sources

Although the Bugis and Makasar people had names for days and months before the arrival of Islam or the Portuguese, ${ }^{37}$ the lontara' never mention dates for events occurring before the seventeenth century. Rather time is reckoned by the length of a king's rule. The Complete Chronicles of Wadjo', for example, states that the eleventh Arung Matowa of Wadjo', La Mungkatjé To Uddamang, ruled for 40 years, and that he was the last chief radja whose corpse was burned. His successor, La Sangkuru' Patau' Muladjadji, embraced Islam; he died in 1610 after a three-year reign. Knowing his dates, therefore, it is possible to count backwards and assign dates to the reigns of earlier rulers. Thus, the first Arung Matowa, La Paléwo To Palipu', ruled from about 1474 to 1482 . One can also calculate the earlier rulers called the Batara; La Tenribali Batara I ruled approximately from 1436 to 1456.

Crawfurd used this technique of backdating in his book the History of the Indian Archipelago, published in 1820. He included in the book a chart of the South Sulawesi rulers in chronological order beginning in the fifteenth century. Noorduyn, who worked his calculations more systematically, identified what he calls the "first historical king" of Gowa, I Mariogau', with the title Tunipalangga Ulaweng, as reigning from 1548 to 1566 . Concerning his father's reign, the records note only that he ruled for 30 years. Noorduyn also identified the first historical king of Boné as La Itja, who had the mortuary title of "he who fought on his staircase" because he was killed by the common people; he ruled from 1584 to $1595 .^{38}$ A lontara' contained at the Institute for South and Southeast Sulawesi Culture gives the lengths of reign as far back as the second king of Boné, La Ummase Tumulaijjé Panreng, who reign from approximately 1424 to 1441 . The length of the first ruler's reign is not known precisely, though the lontara' estimates that it lasted for four pariamang, or 32 years, so he probably ruled from about 1392 to 1424 .

In the matter of dating, corroborating evidence for events

36. $\mathrm{Ph}$. O. L. Tobing, in his introduction to the History of Wadjo' by Abdurazak Daêng Patunru (Makasar: Jajasan Kebudajaan Sulawesi Selatan dan Tenggara, 1964).

37. Noorduyn ("Origins of South Celebes Historical Writing," p. 92, note 26) notes that the Bugis calendar consisted of twelve solar months with Sanskritic names but arranged in a different sequence from either the Indian or Javanese calendars. Months were divided into weeks of five days, some of whose names are the same as in Java. The five-day week, called a sipasa' (the same as sepasar, meaning one market cycle) is still known today. The lontara bilang of Andi Oddang, former Arung Matowa of Wadjo', indicates that a seven-day week also existed.

38. Noorduyn, "Origins of South Sulawesi Historical Writing," p. 151 . 
described in the 1ontara' can sometimes be found in European sources. Unfortunate1y, such records (mainly Dutch or Portuguese) for South Sulawesi are few in comparison with some other areas of Indonesia. The historian, however, must carefully compare such records as do exist with the information in the lontara' in order to arrive at a more complete picture.

\section{In Conclusion}

It is most unfortunate that, despite the rich historiographical resources which the lontara' provide, the study of South Sulawesi history has never been undertaken in an intensive or systematic way. It would seem especially necessary for Indonesian scholars to delve into the origins of their own history rather than leave the field to foreign researchers, as has increasingly become the case. Does not the study of one's own history nurture and develop a positive feeling of nationality as well as the much-talked-of sense of national identity? We must not allow apathy to undermine our desire to illuminate the darkness which overshadows our national history. Let us now hope that the time of "the rooster crowing loudly on the rooftop but afraid to fly down and join his friends" is over and that the time of "the turtle who makes no sound but has many eggs" has begun. 